\title{
Femoral Diaphyseal Fractures Fixation Technique Using an Adjustable Nylon Tie in Dog (Canis lupus familiaris) and Cat (Felis catus domesticus)
}

\author{
Bruna Martins da Silva ${ }^{1}$, Ivan Felismino Charas dos Santos ${ }^{1,2}$, Danuta Pulz Doiche ${ }^{3}$, \\ Maria Gabriela Picelli de Azevedo ${ }^{4}$, David José de Castro Martins', \\ Barbara Wagner Duarte Ferraz de Camargo', Manuela Agostinho', Gustavo Manea Ferreira', \\ Marina Paiva Branco' \& Gabriella Cunha Salewski'
}

\begin{abstract}
Background: Adjustable nylon ties polyamide 6.6 is devices produced from the same material of surgical nylon wire and have been used in different surgical procedures in small animals and in human patient. Reports regarding the use of these devices as secondary fixation technique of femoral diaphyseal fractures in animals are rare in the literature. The aim of the present report case was to describe the use of adjustable nylon tie polyamide 6.6 as secondary fixation technique in a 3 -year-old dog and 4-month-old cat, diagnosed with femoral diaphyseal fractures.

Cases: Case 1. A 3-year-old female dog was presented with reluctance to support the left hind limb, with 5 days' duration. Pain and edema on the left femoral diaphyseal region was identified. The limb was submitted to radiographic exam and revealed a closed, complete and comminuted fracture of the diaphysis of the femur, and was decided to perform a surgical stabilization by open reduction through primary fixation with intramedullary pin, and secondary fixation of bone fragments with adjustable nylon ties polyamide 6.6, as a substitute of steel cerclage wire. The bone fragments were alignment and fixated with five polyamide nylon ties. The excess was removed with a scalpel blade along the lock. Seven days after surgery the skin sutures were removed and were observed reluctance to support the left hind limb. Physiotherapy sessions were prescribed. Forty days after the surgery was performed a radiographic exam of the left hind limb which revealed alignment of the bone axis. Six months after the surgery, the owner reported that the dog supported the left hind limb. Case 2. A 4-month-old female cat was presented with history of trauma, with $24 \mathrm{~h}$ 's duration, and reluctance in supporting the left hind limb. On physical examination there was identified pain on the left femoral diaphyseal region. Radiographic examination revealed a closed, complete and simple fracture of the diaphysis of the femur, and a surgical stabilization through primary fixation with intramedullary pin, and secondary fixation with three polyamide nylon ties was performed. Seven days after the surgery were observed reluctance to support the left hind limb. Three months after the surgery, the owner was contacted and he reported that the cat was supported the limb.

Discussion: Adult dogs are more susceptible to diaphyseal fractures and so does the dog in the present report. On the other hand, young cats present high metaphyseal fracture rates due to the metaphyseal growth plate. However, the cat in the present report was different since it was 4-month-old and presented diaphyseal fracture. Different from steel cerclage wires, polyamide nylon ties were used as secondary fixation in diaphyseal fractures for the reason that of their stability in this kind of fracture, no tissue reaction and minimal tissue trauma. The adjustable nylon ties polyamide 6.6 were already used in different surgical procedures in human patients and animals. Complications reported in the literature due to their use were associated with erroneous surgical techniques. Adjustable nylon ties polyamide 6.6 proved to be efficient as bone cerclage device in diaphyseal multiple and simple fracture, as well as gave stability to the herein assessed adult dog and young cat, besides not inducing foreign body reactions.
\end{abstract}

Keywords: small animals, polyamide, bones, cerclage, surgery.

${ }^{1}$ Setor de Cirurgia Animal, Departamento de Cirurgia e Anestesiologia Veterinária (DCAV), ${ }^{2}$ Pós-doutorando em Cirurgia Animal (Bolsista FAPESP), ${ }^{3}$ Setor de Diagnóstico por Imagem, Departamento de Radiologia Veterinária e Reprodução Animal (DRVRA) \& ${ }^{4}$ Setor de Clinica de pequenos Animais, Departamento de Clínica Veterinária (DCV), Universidade Estadual Paulista (UNESP), Faculdade de Medicina Veterinária e Zootecnia (FMVZ), Botucatu, SP, Brazil. CORRESPONDENCE: I.F.C. Santos [ivansantos7 @ hotmail.com - Tel.: +55 (14) 3880-2022]. Setor de Cirurgia Animal, FMVZ - UNESP. Distrito de Rubião Junior s/n. CEP 18618-681 Botucatu, SP, Brazil. 


\section{INTRODUCTION}

Fractures are defined as total or partial bone or cartilage loss, which could be followed by several degrees of soft tissue injury [11]. Fracture reduction can be achieved through different surgical techniques, although the open reduction technique is the most effective one [24]. Orthopedic surgical implants include intramedullary pins, Kirschner wires, orthopedic screws and steel cerclage wire, which is used to improve the stability of the fracture after the primary fixation and to provide interfragmentary static compression [24]. On the other hand, the erroneous use of steel cerclage wires can lead to local vascular injuries; to bone, nervous and connective tissue impairment; and to late callus formation [24].

Adjustable nylon ties are devices produced from the same material of surgical nylon wire, polyamide $6.6[19,21,30]$ and can be sterilized in the autoclave without loose the tensile strength $[1,25,27]$. This device have been used in different surgical procedures of soft tissues in small animals [1,4,5,9,15,17,25,27,29]; orthopedic surgical procedures in human patient $[22,28]$ and in small animals $[10,16]$. Reports regarding the use of the polyamide nylon tie as secondary fixation technique of femoral diaphyseal fractures in dogs and cats are rare in the literature $[3,6,8]$. However, there is no report in the literature concerning using this device in fractures in cats. The authors aim to describe the use of an adjustable nylon tie polyamide 6.6 as a secondary fixation technique in a 3-years-old dog and 4-months-old cat, diagnosed with femoral diaphyseal fractures.

\section{CASES}

Case 1. A 3-year-old non intact female cross breed dog, weighing $15 \mathrm{~kg}$ was presented to the Veterinary Hospital, SP, Brazil, with difficulty to support the left hind limb, with 5 days' duration. According to the owner, the dog had been run over by car, but no therapeutic protocol had been done so far. Water and food intake was not unsettled, and urine and feces were normal. On physical examination there was identified pain and edema on the left femoral diaphyseal region. The remainder of the physical examination was within normal. Blood was collected from the external jugular vein, and placed in a plastic tube containing anticoagulant (EDTA) for the complete blood count (CBC); and placed in another plastic tube without anticoagulant and serum where used to serum biochemical examination (alanine aminotransferase - ALT, urea, creatinine and creatine kinase - CK). Complete blood count, serum biochemical (ALT, urea and creatinine) and urinalysis were within normal limits. Creatine kinase $(\mathrm{CK})$ remained above the reference values (176 $\mathrm{UI} / \mathrm{L}$, reference value: 1.15 - $28.40 \mathrm{UI} / \mathrm{L}$ ).

The left hind limb was subjected to radiographic examination on mediolateral and craniocaudal view in an X-ray machine $\left(\mathrm{CRX} D \mathrm{DM} 125^{\circledR}\right)^{1}$. The X-ray revealed a closed, complete and comminuted fracture of the diaphysis of the femur with oblique fracture of the distal fragment and two fragments with longitudinal fracture (Figure 1).

According to radiographic examinations it was decided to perform a surgical stabilization through primary fixation with intramedullary pin and secondary fixation of bone fragments with adjustable nylon ties polyamide 6.6, as a substitute of steel cerclage wire. The owner signed the surgery commitment term to allow the surgical procedure and the use of polyamide nylon ties. The dog was medicated with $30,000 \mathrm{UI} \mathrm{kg}^{-1}$ subcutaneously of penicillin (benzatinbenzilpenicillin, procain benzilpenicillin and potassicbenzilpenicillin) $\left(\text { Pentabiótico }{ }^{\circledR}\right)^{2}$ and premedicated with $4.4 \mathrm{mg} \mathrm{kg}^{-1}$ subcutaneously of carprofen $\left(\operatorname{Rimadyl}^{\circledR}\right)^{3}, 0.3 \mathrm{mg} \mathrm{kg}^{-1}$ subcutaneously of morphine (Dimorf $\left.{ }^{\circledR}\right)^{4}$ and $0.05 \mathrm{mg} \mathrm{kg}^{-1}$ intramuscularly of acepromazine $\left(\text { Acepran }{ }^{\circledR}\right)^{5}$. Anaesthesia was induced with $2.5 \mathrm{mg} \mathrm{kg}^{-1}$ intravenous of propofol $\left(\text { Diprivan }^{\circledR}\right)^{6}$ and maintained with isoflurane $\left(\text { Forane }^{\circledR}\right)^{7}$.

The dog was placed in right lateral recumbence and an open reduction of the fracture was performed through lateral approach of the femur [24], and an intramedullary pin was introduced in retrograde direction. The bone fragments were alignment and fixated with five adjustable nylon ties polyamide 6.6 [length - 381 $\mathrm{mm}$; width $4.9 \mathrm{~mm}$; minimal traction system - $22.6 \mathrm{~kg}$; minimal tension $54.4 \mathrm{kgf}$ (Abraçadeira de nylon $\left.\left.{ }^{\circledR}\right)^{8}\right]$, with the lock positioned in lateral position (Figure 2A). Nylon ties adjustments were performed with hemostat clamp Kelly and the distance between them were depended on the position of the fragments. The excess was removed with a scalpel blade along the lock. (Figure 2B). Finally, the muscular layer and skin edges were sutured. The nylon tie was sterilized in autoclave, $121^{\circ} \mathrm{C}$ for $30 \mathrm{~min}$ [26] previously the surgical procedure.

Radiographic examination of the left hind limb on mediolateral and craniocaudal view was performed immediately after the surgery and revealed bone axis 
alignment, presence of intramedullary pin, gas between soft tissues, and fracture and bone fragments coaptation (Figure 3). The dog recovered uneventfully from surgery, and was prescribed $15 \mathrm{mg} \mathrm{kg}^{-1}$ TID orally for 4 days of dipyrone (Dipirona Sódica $\left.{ }^{\circledR}\right)^{9} ; 4.4 \mathrm{mg} \mathrm{kg}^{-1}$ SID orally for 5 days of carprofen $\left(\operatorname{Rimadyl}^{\circledR}\right)^{10} ; 1 \mathrm{mg}$ $\mathrm{kg}^{-1}$ TID orally for 4 days of tramadol hydrochloride $\left(\text { Tramal }^{\circledR}\right)^{11}$; and $25 \mathrm{mg} \mathrm{kg}^{-1}$ BID orally for 15 days of cephalexin $\left(\operatorname{Keforal}^{\circledR}\right)^{12}$. At the recheck examination seven days after surgery the skin sutures were removed and were observed difficulty to support the left hind limb. The CBC, ALT, creatinine and CK was within normal limits, and no alterations were observed on the physical examination. Physiotherapy sessions were prescribed. The owner did not report any physiological alteration 20 days after surgery, and it is worth highlighting that physical rest and physiotherapy were not attended. The dog avoided supporting the left hind limb during the physical examination, but there were no signs of local infection. Forty days after the surgery was performed a radiographic exam of the left hind limb which revealed alignment of the bone axis, irregular lamellar bone proliferation on the fracture focus. The cortical bone was thickness and fracture lines were visible (Figure 4). The dog was partially to supporting the limb. Six months after the surgery, the owner was contacted by telephone for the recheck appointment and radiographic examination. He was unable to return to the Veterinary Hospital to perform the exams; however he reported absence of any abnormality, and the dog was totally capable of supporting its left hind limb.

Case 2. A 4-month-old intact female cross breed cat, weighing $1.5 \mathrm{~kg}$ was presented to the same Veterinary Hospital with history of trauma, with 24 hour's duration. The main clinical sign was avoiding supporting the left hind limb, and no therapeutic protocol had been done. Water and food intake was decreased, and urine and feces were normal. On physical examination there was identified pain on the left femoral diaphyseal region. The remainder of the physical examination was within normal. Blood was collected from the external jugular vein, and used to perform CBC, ALT, creatinine and CK exams, and was within normal limits. The left hind limb was subjected to radiographic examination on mediolateral and craniocaudal view in X-ray machine $\left(\mathrm{CRX} \text { DM } 125^{\circledR}\right)^{1}$. The X-ray revealed a longitudinal closed, complete and simple fracture of the diaphysis of the femur and medullar exposition area (Figure 5). The decision was made to perform surgical stabilization through primary fixation with an intramedullary pin and secondary fixation with adjustable nylon ties polyamide 6.6. The owner signed the same surgery term of dog's case.

The cat was medicated with $30,000 \mathrm{UI} \mathrm{k^{-1 }}$ subcutaneously of penicillin [benzatinbenzilpenicillin, procain benzilpenicillin and potassicbenzilpenicillin $\left.\left(\text { Pentabiótico }{ }^{\circledR}\right)^{2}\right]$, and premedicated with $0.3 \mathrm{mg} \mathrm{kg}^{-1}$ subcutaneously of morphine (Dimorf $\left.{ }^{\circledR}\right)^{4}, 0.05 \mathrm{mg} \mathrm{kg}^{-1}$ intramuscularly of acepromazine $\left(\text { Acepran }^{\circledR}\right)^{5}$ and 0.5 $\mathrm{mg} \mathrm{kg}^{-1}$ intravenously of diazepam $\left(\text { Diazepam }^{\circledR}\right)^{13}$. Anaesthesia was induced with $2.5 \mathrm{mg} \mathrm{kg}^{-1}$ intravenously of propofol (Diprivan $\left.{ }^{\circledR}\right)^{6}$ and maintained with isoflurane $\left(\text { Forane }^{\circledR}\right)^{7}$. The surgical technique was similar to dog's case. However, only three adjustable nylon ties polyamide 6.6 [length - $381 \mathrm{~mm}$; width - $4.9 \mathrm{~mm}$; minimal traction system $22.6 \mathrm{~kg}$; minimal tension - 54.4 $\mathrm{kgf}$ (Abraçadeira de nylon $)^{8}$ ] were used. The limb was subjected to radiographic examination on mediolateral and craniocaudal view right after the surgery, which depicted bone axis alignment, intramedullary pin, gas between soft tissues and the coaptation of fracture fragments (Figure 6).

After the cat recovered from surgery, was prescribed $1 \mathrm{mg} \mathrm{kg}^{-1}$ BID orally for 4 days of cetoprofeno $\left(K_{\text {Ketoflex }}^{\circledR}\right)^{14} ; 0.5 \mathrm{mg} \mathrm{kg}^{-1}$ TID orally for 4 days of tramadol hydrochloride $\left(\operatorname{Tramal}^{\circledR}\right)^{11}$; and $20 \mathrm{mg}$ $\mathrm{kg}^{-1}$ BID orally for 10 days of amoxicillin suspension $\left(\text { Amoxil }{ }^{\circledR}\right)^{15}$. Seven days after, the skin sutures were removed, and were observed difficulty to support the left hind limb. The CBC and ALT and creatinine were within normal limits. Three months after the surgery, the owner was contacted through telephone to perform the radiographic exam, but did not show at the recheck appointment, although, reported that the cat already supported the limb normally.

\section{DISCUSSION}

The two cases in the present report described the use of adjustable nylon ties polyamide 6.6 in the secondary fixation of multiple and simple femoral diaphyseal fracture in a dog and young cat, respectively. Few reports regarding the use of the adjustable nylon ties polyamide 6.6 bands as a secondary fixation technique of femoral fractures in dogs and cats are found in the literature. The elevated values of CK of dog were related with muscle 


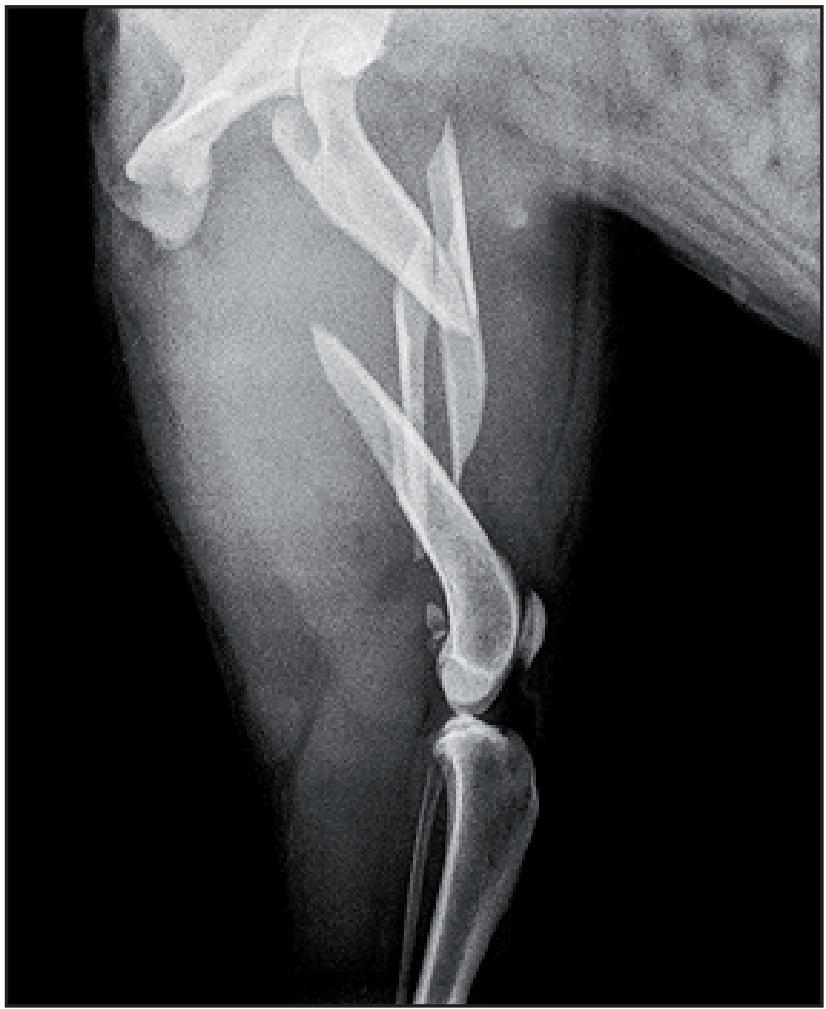

Figure 1. Radiographic exam of the femur and proximal region of tibia of the left hind limb (200 mA, $70 \mathrm{kV}$ - mediolateral view) of a cross breed dog, 3-year-old, $15 \mathrm{~kg}$ of body mass, showing a closed, complete and comminuted fracture of the diaphysis of the femur with oblique fracture of the distal fragment and two fragments with longitudinal fracture; and medullar exposition in the middle third of the femur and increase of the surrounding soft tissue.

trauma. On the other hand, no alterations of $\mathrm{CK}$ values were observed in the cat, probably due to the shorter time between trauma and hospital care.

Adult dogs are more susceptible to diaphyseal fractures, which are mainly caused by trauma resulting from car running over $[11,23,24]$ similar to the herein reported case. However, higher metaphyseal fracture rates are reported for young subjects due to the metaphyseal growth plate $[23,24]$. Although, the cat in the present report was 4 months old and presented diaphyseal fracture.

Femoral diaphyseal fractures caused by trauma represent approximately $20 \%$ to $25 \%$ of the total number of fractures recorded during veterinary medicine routines $[11,24]$. They are treated through different surgical techniques that include intramedullary pins, external skeletal fixators, bone screws, orthopedic plates, Kirschner wires, steel cerclage wires, among others $[2,12,24]$. Device with locking mechanisms similar to the polyamide nylon ties and made from polydioxanone already exists [13]. However, in Brazil is not available, and it gets expensive to order; and on the other hand, the absorbable surgical material could be lead a loose in fracture focus unleashing a decreased or absence of bone instability and increasing the time of the remodeling time. With regard to the present cases, the choice was made to use the adjustable nylon ties polyamide 6.6 for secondary fixation in the diaphyseal fractures due to their stability in this kind of fracture, no tissue reaction and because they induce minimal tissue trauma; different from steel cerclage wires $[10,16]$. Furthermore, the chances of steel wire cerclage loosening after it is used in fracture stabilization are higher than adjustable nylon ties, since the lock system of the nylon ties stops the loosening occurrence [14], as seen in the present case report. The use of adjustable nylon ties to replace steel cerclage wire was explained to the owner and he authorized the surgery by signing the consent form. This procedure is necessary when devices under study are supposed to be used in the surgical protocol.

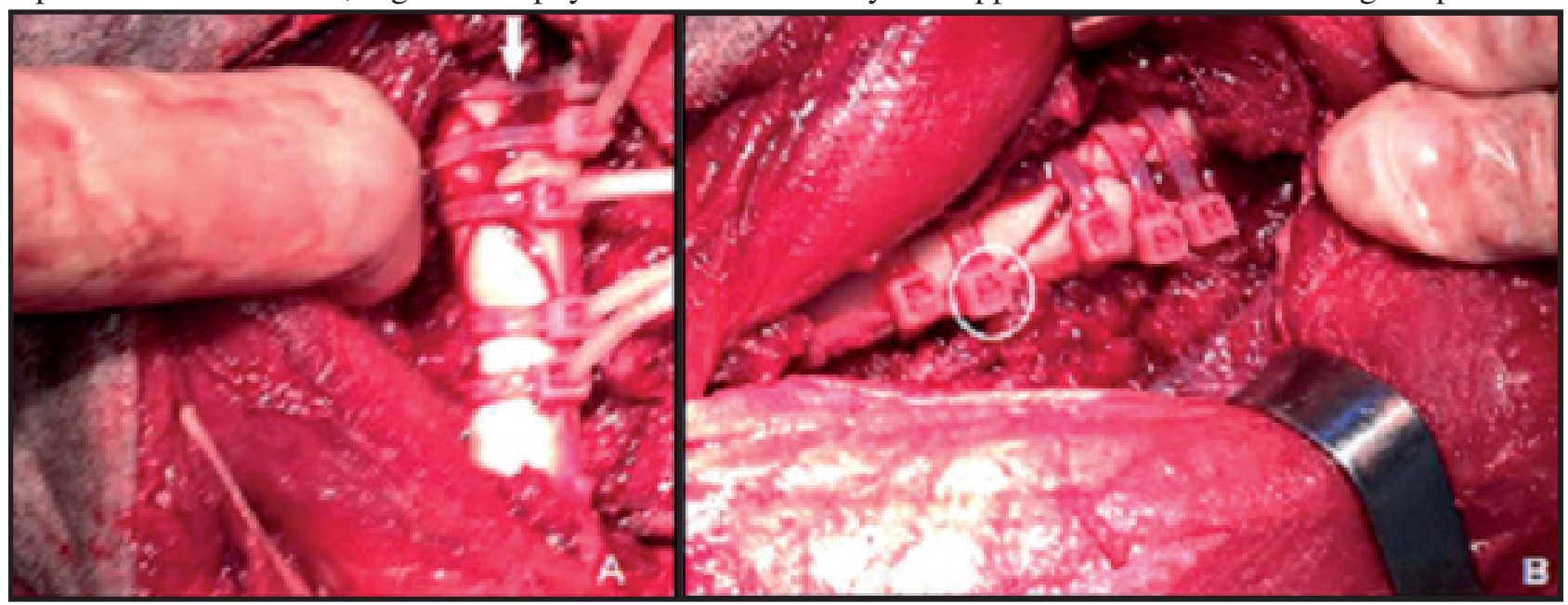

Figure 2. Photography from the transoperatory of femoral osteosynthesis in cross breed dog, 3-year-old, $15 \mathrm{~kg}$ of body mass, diagnosed with a closed, complete and comminuted fracture. A- Lateral placement of adjustable nylon ties polyamide 6.6 bands (length - 381 mm; width 4.9 mm; minimal traction system - $22.6 \mathrm{~kg}$; minimal tension $54.4 \mathrm{kgf}$ ) [white arrow] on the fragments. B- Adjustable nylon ties polyamide 6.6 bands after excess has been removed with a scalpel blade along the band's lock [white circle]. 


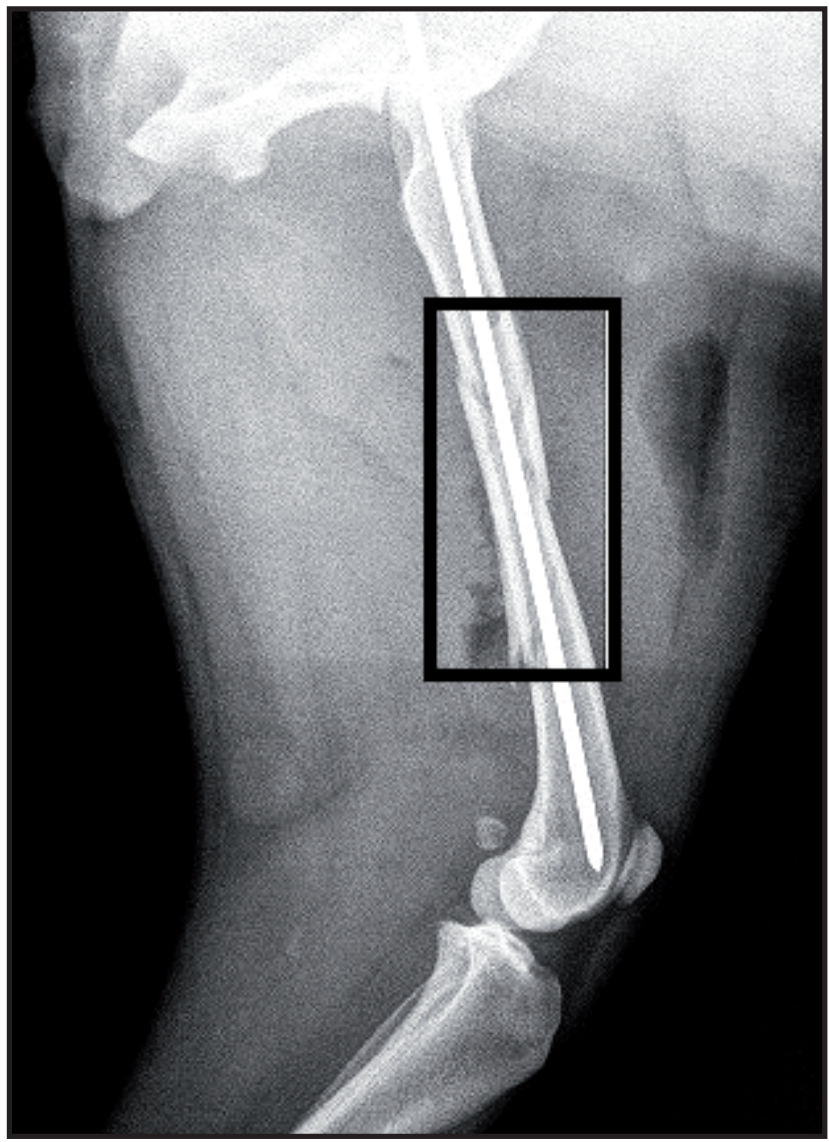

Figure 3. Radiographic exam of the femur and proximal region of tibia of the left hind limb (200 mA, $70 \mathrm{kV}$ - mediolateral view) of a cross breed dog, 3-year-old, $15 \mathrm{~kg}$ of body mass, immediately after the surgery, showing bone axis alignment, presence of intramedullary pin, gas between soft tissues, and fracture and bone fragments coaptation [black rectangle].

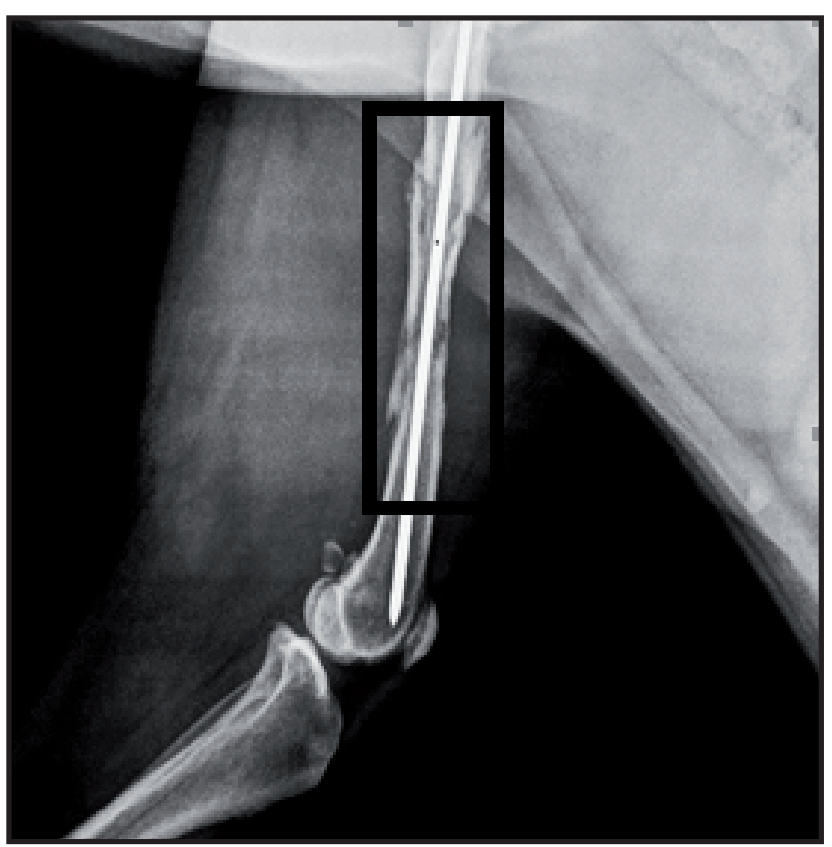

Figure 4. Radiographic exam of the femur and proximal region of tibia of the left hind limb (200 mA, $70 \mathrm{kV}$ - mediolateral view) of a cross breed dog, 3-year-old, $15 \mathrm{~kg}$ of body mass, forty days after the surgery, showing bone axis alignment, irregular lamellar bone proliferation on the fracture focus, cortical bone thickness and fracture lines visible [black rectangle].

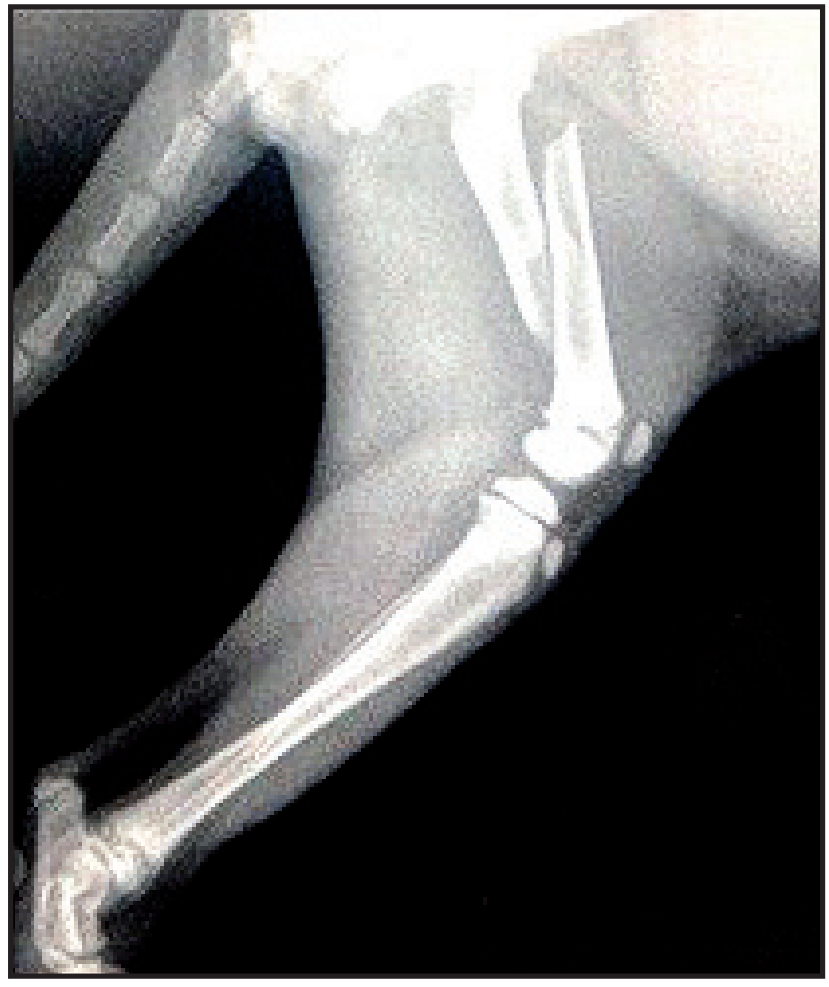

Figure 5. Radiographic exam of the femur and tibia of the left hind limb (200 mA, $70 \mathrm{kV}$ - mediolateral view) of a cross breed cat, 4-month-old, $1.5 \mathrm{~kg}$ of body mass, revealing a longitudinal, closed, complete and simple fracture of the diaphysis of the femur and medullar exposition area.

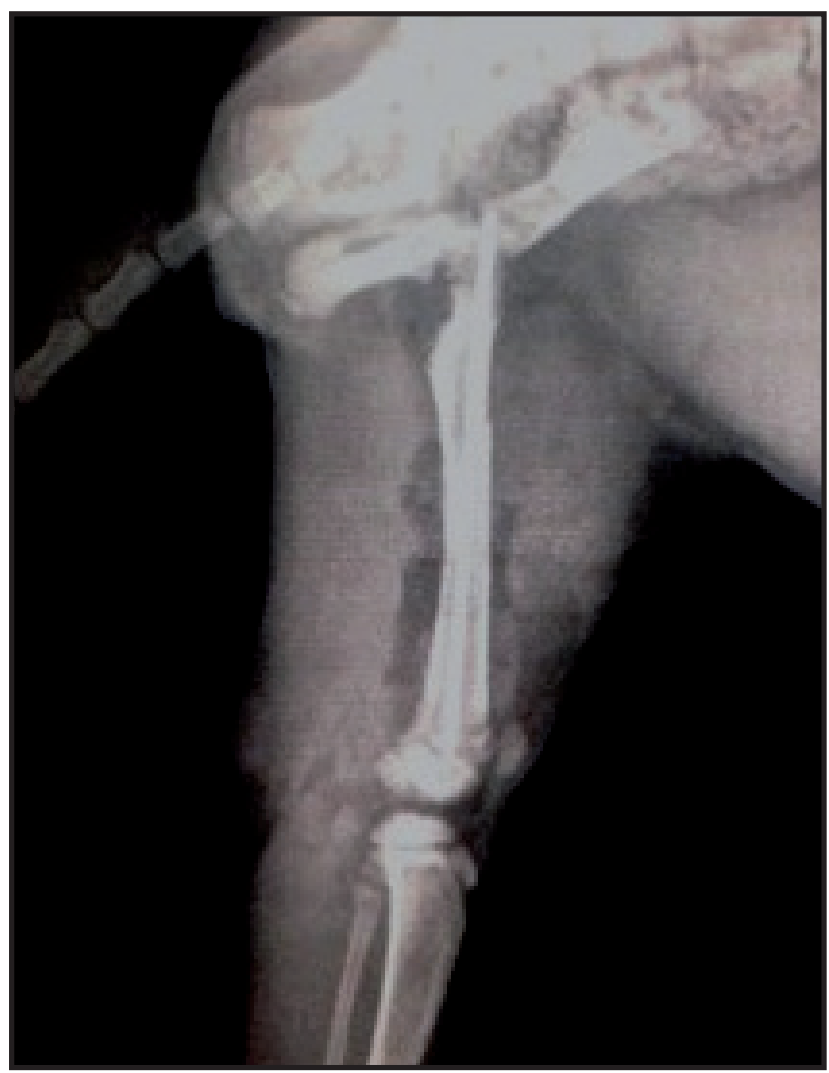

Figure 6. Radiographic exam of the femur and proximal region of tibia of the left hind limb (200 mA, $70 \mathrm{kV}$ - mediolateral view) of a cross breed cat, 4-month-old, $1.5 \mathrm{~kg}$ of body mass, immediately after the surgery, showing bone axis alignment, presence of intramedullary pin, gas between soft tissues, and fracture fragments coaptation [black rectangle]. 
The veterinary community reports the use of such devices as an act of negligence to the animal [19]. Nevertheless, adjustable nylon ties polyamide 6.6 was already used in different surgical procedures [7,31], including orthopedic surgeries, applied to human $[22,28]$. Complications reported in the literature $[4,18,20,32]$ due to the use of polyamide nylon ties were associated with erroneous surgical techniques. Their use in surgeries procedures must follow the correct surgical technique and they have to be sterilized in the autoclave before their use; tensile strength losses were not recorded after sterilization $[19,21,25]$. Orthopedic complications associated with the use of adjustable nylon ties in dogs were reported [4]. Nonetheless, these complications have been associated with erroneous surgical techniques, since the polyamide nylon ties were used for secondary fixation in all the reported cases, even when the fractures did not demand any bone cerclage.

Different from the steel cerclage wire, the polyamide nylon ties was easy and quick application, and able to adjust into the fracture focus and allowed performing readjustments without breaking [16].

The use of adjustable nylon ties in association with an intramedullary pin as bone cerclage in femur oblique fractures in 12 rabbits was performed [6]. The authors observed a bone remodeling within 28 days after surgery, as well the absence of foreign body reaction and bone histological changes. It was not possible to conduct any histological study in the present study, since the owners did not authorize it.

Efficacy, stabilization and complications of using adjustable nylon ties and steel wire cerclage in mandibular symphysis fractures in 12 adult cats were performed [10], and were observed the viability of using this device. The use of polyamide nylon ties in mandibular symphysis allowed a strong fixation and bone remodeling. In conclusion, the use of adjustable nylon ties polyamide 6.6 as bone cerclage device in diaphyseal multiple and simple fractures in adult dog and in young cat assessed in the present case proved to be efficient and to provide fracture stability, besides not inducing foreign body reactions. More studies regarding to efficiency of adjustable nylon ties polyamide 6.6 ban$\mathrm{ds}$ as bone cerclage device in fracture must be conduct.

\section{MANUFACTURERS}

${ }^{1}$ CRX Indústria e Comércio de Equipamentos de Raio X. São Paulo, SP, Brazil.

${ }^{2}$ Laboratórios Fort Dodge Saúde Animal. São Paulo, SP, Brazil.

${ }^{3}$ Zoetis Laboratórios. São Paulo, SP, Brazil.

${ }^{4}$ Laboratórios Cristália Produtos Químicos e Farmácia. São Paulo,

SP, Brazil.

${ }^{5}$ Laboratórios Vetnil. São Paulo, SP, Brazil.

${ }^{6}$ Laboratórios AstraZeneca. São Paulo, SP, Brazil.

${ }^{7}$ Baxter Healthcare Corporation Laboratories, Itapevi, SP, Brazil.

${ }^{8}$ Wurth do Brasil. São Paulo, SP, Brazil.

${ }^{9}$ Gemed Farma laboratórios. São Paulo, SP, Brazil.

${ }^{10}$ Laboratório Zoetis Indústria de Produtos Veterinários. São Paulo,

SP, Brazil.

${ }^{11}$ Laboratórios Pfizer. São Paulo, SP, Brazil.

${ }^{12}$ Laboratórios Antibióticos do Brasil. São Paulo, SP, Brazil.

${ }^{13}$ Teuto Brasileiro Laboratórios. São Paulo, SP, Brazil.

${ }^{14}$ Mundo Animal Laboratórios. São Paulo, SP, Brazil.

${ }^{15}$ Glaxo Smith Kline, Rio de Janeiro, RJ, Brazil.

Declaration of interest. The authors report no conflicts of interest. The authors alone are responsible for the content and writing of the paper.

\section{REFERENCES}

1 Barros B.J., Sanches A.W.D. \&Pachaly J.R. 2009. Utilização de abraçadeira de náilon 6.6 (poliamida) como método de ligadura de pedículos ovarianos e coto uterino em ovário-histerectomia eletiva em cadelas (Canis familiaris). Arquivo de Ciências Veterinárias e Zoologia da Unipar. 12(1): 4760 - 4769.

2 Beale B. 2004. Orthopedic clinical techniques femur fracture repair. Clinical Techniques in Small Animal Practice. 19(3): 134-150.

3 Brandão C.V.S., Antunes P.A.U.M., Estanislau C.A., Mamprim M.J., Teixeira L., Padovani C.R., Marinho P.V.T. \& Minto B.W. 2013. Cinta de náilon como cerclagem óssea - estudo experimental em coelhos e ratos. Semina Ciência Agrária. 34(6): 2903-2914.

4 Bregadioli T., Ferrigno C.R.A., Ferreira M.P., Ferraz V.C.M., Bó I.S.D., Santos J.F., Paes F., Galeazzi V.S., Marinho P.V.T. \& Macedo A.S. 2017. Complicações relacionadas ao uso de abraçadeira de náilon como implante ortopédico. Revista CFMV. 23(72): 67-71.

5 Cadeddu J.A. 2001. Hemostatic laparoscopic partial nephrectomy: cable-tie compression. Urology. 57(3): 562-566.

6 Carrillo J.M., Sopena J.J., Rubio M., Redondo J.I., Serra I. \& Soler C. 2005. Experimental use of polyamide bands in combination with intramedullary pinning for repair of oblique femoral fractures in rabbits. Veterinary Surgery. 34: 387-392. 
7 Chávez-Cartaya R., Jiron-Vargas A., Pinto S., Carretta M., Pino-DeSola G. \& Vegas A.M. 1992. Adjustable nylon ties for abdominal Wall closure. American Journal of Surgery. 163: 609-612.

8 Costa Neto J.M., Lima A.E.S., Ória A.P., Ferreira Filho E.M. \& Teixeira D.M. 2014. Análise histopatológica das reações teciduais produzidas pelo implante de fio e de braçadeira de náilon. Enciclopédia biosfera. 10(18): 291-299.

9 Costa Neto J.M., Teixeira E.M., Ferreira Filho E.M., Toríbio J.M.M.L., Almeida Filho C.H.R. \& Moraes V.J. 2009. Braçadeiras de náilon para hemostasia preventiva da ováriossalpingohisterectomia em gatas. Revista Brasileira de Saúde e Produção Animal. 10(3): 615-624.

10 Cunha M.G.M.C.M., Pippi N.L., Santos Junior E.B., Gomes K., Fontes E.B., Cunha J.P.M.C.M., Serafini G.M.C., Kloc K.A. \& Togni M. 2010. Cerclagem com abraçadeira de náilon ou de fio de aço no reparo de fraturas experimentais de sínfise mandibular em gatos. Acta Scientiae Veterinária. 38(4): 363-369.

11 Denny H.R. \& Butterwoth S.J. 2006. Fêmur. In: Denny H.R. \& Butterwoth S.J. (Eds). Cirurgia Ortopédica em Cães e Gatos. 4.ed. São Paulo: Roca, 383p.

12 Gonçalves L.P. 2009. Use of nylon bands for alternative surgical treatment of oblique fractures in dogs. In: Proceedings of the 34th World Small Animal Veterinary Congress (São Paulo, Brazil). p.850.

13 Hoglund O.V., Hagman R., Olsson K., Mindermark J., Borg N. \& Lagerstedt A.S. 2011. A new resorbable device for ligation of blood vessels - a pilot study. Acta Veterinaria Scandinavica. 53: 47 - 53.

14 Hulse D.A. \& Johnson A. L. 2002. Ortopedia. In: Fossum T.W. (Ed). Cirurgia de Pequenos Animais. São Paulo: Roca, pp.787-1113.

15 Santos I.F.C., Del Poente M.D., Brombini G.C., Gomes M.V.F., Silva B.M., Rahal S.C., Tannus F.C.I., Góis F.M.D. \& Azevedo M.G.P. 2017. Hemostasis Technique Using an Adjustable Nylon Tie in Dog with Splenic Hematoma and Lymphoid Hyperplasia. Acta Scientiae Veterinariae. 45(1): 215 - 217.

16 Kavinski L.C., Presotto E.J. \& Silva E.G. 2002. Avaliação da fita de poliamida sintética (Nylon) na redução de fraturas em cães e gatos. In: Anais do XXIII Congresso Brasileiro de Clínicos Veterinários de Pequenos Animais ANCLIVEPA (Brasília, Brasil). 1 CD-ROM.

17 Lima A.F.M., Luna S.P.L, Rodrigues M.M.P. \& Quitzan J.G. 2010. Avaliação histológica e videolaparoscópica de ligaduras dos pedículos ovarianos realizados com mononáilon agulhado ou abraçadeiras autoestáticas de náilon em cadelas submetidas ováriosalpingohisterectomia pela técnica do gancho. Ars Veterinaria. 26(2): 66-70.

18 Macedo A.S., Dal-Bo I.S., Quadros A.M., Brambatti G., Reis K.D.H.L., Brun M.V., Alievi M.M. \& Beck C.A.C. 2012. Complications associated with ovariohysterectomy using nylon tie-rap as a hemostatic method. Acta Scientiae Veterinariae. 40: 1086.

19 Marujo R.B., Luna S.P.L, Lima A.F.M. \& Santos I.F.C. 2013. Abraçadeira autoestática de náilon na cirurgia veterinária: revisão de literatura. Nosso Clínico. 96: 50-54.

20 Mesquita L.R., Rahal S.C., Matsubara L.M., Mamprim M.J., Foschini C.R., Faria L.G. \& Kano W.T. 2015. Bilateral hydronephrosis and hydroureter after ovariohysterectomy using nylon cable tie: a case report. Veterinarni Medicina. 60(1): 52-56.

21 Miranda A.H., Silva L.A.F., Tavares G.A., Amaral A.V.C. \& Miranda H.G. 2006. Abraçadeira de náilon: Resistência à tração em testes físicos e seu emprego como cerclagem no fêmur de cães. Ciência Animal Brasileira. 3: 299-307.

22 Partridge A.J. \& Evans P.E. 1982. The treatment of fractures of the shaft of the femur using nylon cerclage. The Journal of Bone and Joint Surgery. 64(2): 33-37.

23 Paulino L.P.V.L. 2009. Caracterização das complicações na osteossíntese de ossos longos. Dissertação de mestrado. 149f. Lisboa, Portugal. Dissertação (Mestrado em Medicina Veterinária). Curso de Pós-graduação em Ciência Veterinária, Universidade Técnica de Lisboa.

24 Piermattei D., Flo G. \& Decamp C. 2009. Fraturas do fêmur e da Patela. Ortopedia e Tratamento de Fraturas de Pequenos Animais. 4.ed. São Paulo: Roca, pp.580-636.

25 Santos I.F.C., Bene M. \& Gaspar B. 2012. Eficácia dos métodos de antissepsia e esterilização da abraçadeira autoestática de náilon. Revista Científica Medicina Veterinária. 12(22): 132-135.

26 Santos I.F.C., Canda R., Augusto L., Bambo O. Mataveia G. \& Oliveira K.C. 2012. Eficácia da abraçadeira e do fio de náilon na deferentectomia e laqueação dos ductos deferentes em cães adultos (Estudo comparativo). ARS Veterinaria. 28(2): 75-84. 
27 Schimidt T.L. \& Davis W.M. 1981. Intraoperative use of nylon bands in fracture fixation. Clinical Orthopaedics and Related Research. 154(341): 341-343.

28 Silva L.A.F., Araujo G.R.S., Miranda A.H., Rabelo R.E., Garcia A.M., Silva O.C., Araujo I.F., Macedo S.P., Sousa J.N., Fioravanti M.C.S., Oliveira K.S., Amaral A.V.C. \& Silva E.B. 2004. Ovariohisterectomia em cadelas: uso da abraçadeira de náilon da hemostasia preventiva. Ciência Animal Brasileira. 5: 100-102.

29 Silva L.A.F., França R.O., Vieira D., Souza V.R., Franco L.G., Moura M.I., Silva M.A.M., Trindade B.R., Costa G.L. \& Bernardes K.M. 2006. Emprego da abraçadeira de náilon na orquiectomia em equinos. Acta ScientiaeVeterinariae. 34(3): 261-266.

30 Sorbello A.A., Giudugli J.N. \& Andretto R. 1999. Nova alternativa para ligaduras em cirurgias vídeo-endoscópicas ou convencionais, com emprego de fitas de náilon em estudo experimental. Revista Brasileira de Coloproctologia. 19(1): 2426-2431.

31 Werner R.E., Straughan A.J. \& Vezin D. 1992. Nylon cable band reactions in ovariohysterectomized bitches. Journal of the American Veterinary Medical Association. 200: 64-66. 